\title{
Silica Mesoporous Materials -an Efficient Sorbent for Wine Polyphenols Separation
}

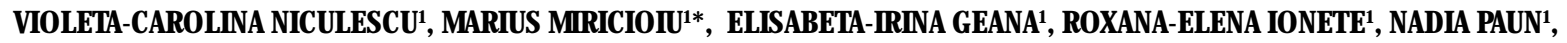 \\ VIORICA PARVULESCU² \\ ${ }^{1}$ National R\&D Institute for Cryogenics and Isotopic Technologies- ICSI Rm. Valcea, $4^{\text {th }}$ Uzinei Str. , 240050, Rm. Valcea, Romania \\ 2llie Murgulescu Institute of Physical Chemistry, Romanian Academy, 202 Splaiul Independentei , 060021, Bucharest, Romania
}

\begin{abstract}
Highly ordered-pore SBA-15 was synthesized by co-condensation of tetraethylorthosilicate (TEOS) and 3aminopropyltriethoxysilane (APTES) using an amphiphilic block copolymer as structure-directing agent. The BET, EDX, TGA-DSC and SEM analysis have been used for sorbent characterization. The adsorption properties of the calcined mesoporous silica SBA-15 material appears to be a consequence of the silanol groups presence that are active sites for adsorption, were evaluated in the clarification process of two types of red wines. The purpose of this study was the investigation of the total polyphenols content (reduction), the selectivity and stabilization for some compounds (phenolic acids, epicatechin, and catechin) and the chromatic characteristics of wine. HPLC chromatograms exhibit the retention of quercetin and transresveratrol, catechin, epicatechin, rutin, and phenolic acids. The decrease in the polyphenolic compounds content in red wines avoids the oxidative browning process without modification of wine color. Due to their beneficial to human health thanks to antioxidative, antiinflamatory, antiviral, cardioprotective, anticarcinogenic and antimutagenic properties the polyphenolic extract might prove interesting as pharmaconutrients or as dietary sources.
\end{abstract}

Keywords: HPLC, mesoporous, polyphenols, SBA-15; wine

Adsorption technology has been used for the removal of organic compounds [1]. Some research presented the removal of phenolic compounds using activated carbon as the adsorbent [2-6]. As an alternative to the microporosity and size selectivity of zeolites, the use of a mesoporous silicate as an adsorbent for the removal of phenolic compounds seems to be promising. Mesoporous silicates offer a number of potential advantages of nanoporous materials (IUPAC classification)[7], as adsorbents including larger pore volume and diameter, high surface area and regular channel type structures. It is also possible to manipulate these properties to suit the adsorbate [8]. The discovery of hexagonally ordered mesoporous silica [9] has stimulated a renewed interest in adsorbents [10] and catalysts design because of their unique large surface area, well-defined pore size and pore shape.

SBA-15 mesoporous silica of hexagonal-ordered pore structure, synthesized using amphiphilic triblock copolymers as the pore-directing agents and under acidic conditions has received great attention in recent years because of its relatively large pore diameter and high hydrothermal stability in comparison to MCM-41, its analogue in the M41S family discovered by Mobil in 1992 $[9,11,12]$. SBA-15 is a combined micro- and mesoporous material with hexagonally ordered tunable uniform mesopores (4-14 nm). The size of the micropores was found to depend on the synthesis conditions and can vary between 0.5 and $3 \mathrm{~nm}$ in size $[13,14]$. It consists of thick microporous silica pore walls ( $3-6 \mathrm{~nm}$ ) responsible for the high hydrothermal stability of SBA-15 compared to other mesoporous materials.

Wine is an alcoholic beverage made from grapes, generally Vitis vinifera, fermented without the addition of sugars, acids, enzymes, water, or other nutrients. In many countries, wine is a traditional product, made from ancient times, with important economic and social implications.
It is known that the aroma of wine is due to over a thousand volatile compounds found in wine, with concentrations from a few ppms up to $10-15 \%$ mass concentration. There were identified several classes of compounds in wine aroma profile, the most important being alcohols, esters, acids, ketones, aldehydes, ethers, lactones, sulphur compounds, nitrogen and phenolic compounds. All these compounds play an important role in characterizing the aroma of wine. Browning and lack of color, aroma and taste constitute the main oenological problems during storage for wine producers. Browning of wines is a result of phenols oxidation to quinones and of condensation reactions between phenolic compounds with the formation of stable colored polymers.

The polyphenolic content depends on the grape variety, vineyard location, cultivation system, climate, soil type, vine cultivation practices, harvesting type, production process and aging [15]. The profile of phenolic compounds is extensively studied in wines produced with Vitis vinifera grapes [16], contrary to what is observed in common wines made from Vitis labrusca grapes [17]. Phenolic compounds have been related to the antioxidant activity of red wines [18]. Antioxidants protect against free radicals, and are important tools in obtaining and preserving good health. Therefore, the antioxidant profiles of numerous compounds are frequently compared in order to identify the mostpotent ones [19].

The aim of this study was to investigate the potential use of mesoporous SBA-15 as a sorbent of red wines polyphenols.

\section{Experimental part}

Materials and methods

SBA-15 synthesis and characterization

In the typical synthesis, TEOS (tretaethylorthosilicate) purchased from Sigma Aldrich (Steinheim, Germany) was introduced to an aqueous $\mathrm{HCl}$ (Sigma Aldrich - Steinheim,

\footnotetext{
* email: marius.miricioiu @icsi.ro; Phone: +40250732744
} 
Germany) solution containing triblock copolymer P123 (EO20PO 70EO20) (Sigma Aldrich - Steinheim, Germany) (initially stirred and refluxed for $24 \mathrm{~h}$ at $35^{\circ} \mathrm{C}$ ) and hydrolyzed for $24 \mathrm{~h}$ under stirring at $35^{\circ} \mathrm{C}$. After this time, the reaction mixture is autoclaved at $120^{\circ} \mathrm{C}$ for $24 \mathrm{~h}$, and then it is filtered, washed and dried. The obtained powder is calcinated at $600{ }^{\circ} \mathrm{C}$ for $8 \mathrm{~h}$ in order to obtain SBA- 15 with highly ordered structure.

Nitrogen physisorption measurements were performed at $-196^{\circ} \mathrm{C}$ using a SORPTOMATIC S1990 (Thermo Scientific, USA). The calcined SBA-15 material was outgassed at $150^{\circ} \mathrm{C}$, prior to the measurements. The IR spectrum was collected on a Bruker Tensor 37 spectrophotometer in the 4000-400 $\mathrm{cm}^{-1}$ range. Thermogravimetric analysis was achieved with a Pyris PerkinElmer instrument. Measurements for SBA- 15 were achieved in $0-800^{\circ} \mathrm{C}$ interval with a rate of $10^{\circ} \mathrm{C} / \mathrm{min}$. The obtained mesoporous materials were characterized by SEM in order to highlight the morphology and porous structure typical to SBA-15 materials. SEM images for SBA-15 put in evidence the typical morphology of these materials.

Identification and quantification of polyphenols from wines before and after treatment with SBA-15

Total phenolic content was estimated using the FolinCiocalteu method for total phenolics [20]. The absorbance was measured at $765 \mathrm{~nm}$ with a Specord 250 UV-Vis Spectrophotometer after incubation for $2 \mathrm{~h}$ at room temperature. The calibration curve, obtained by using gallic acid (Sigma Aldrich - - Steinheim, Germany) solutions (0, $200,400,800,1000 \mathrm{mg} / \mathrm{L}$ ), is described by the equation:

$$
y=0.0027 x+0.061, R^{2}=0.9973
$$

where $y$ is the absorbance value read from the device and $x$ is the equivalent content of polyphenolic compounds expressed as mg gallic acid/L (mg GAE/L).

In order to getthe real value of the total polyphenols, the value obtained from the gallic acid calibration curve must be multiplied with the dilution factor (DF) of the sample, in this case DF being 10.

Phenolic compounds were evaluated by reversed phase - high performance liquid chromatography (RP-HPLC) with direct injection, involving phenolic acids (e.g. gallic acid, p-coumaric acid ferulic acid and trans-cinnamic acid) and flavan-3-ols (e.g., (+) catechin, epicatechin), resveratrol). HPLC determination of individual polyphenols was carried out using a method optimized previously [21] .

Separation was performed using Aquasil C 18 ( $5 \mu \mathrm{m}, 250$ $x 4.6 \mathrm{~mm}$ ) column at $30^{\circ} \mathrm{C}$. The flow rate was $1 \mathrm{~mL} / \mathrm{min}$ and the injection volume was $10 \mu \mathrm{L}$. The gradient of elution for the two solvents was: Solvent A - acetic acid/water $(2: 98 \mathrm{v} / \mathrm{v})$, solvent $B$-methanol, and the gradient program used was: $100 \% \mathrm{~A}$ initially, 0 - $10 \%$ solvent B over $5 \mathrm{~min}$, followed by 10 - 20\% solvent B over 15 min, $20-30 \%$ solvent $B$ for $15 \mathrm{~min}, 30-40 \%$ solvent $B$ for $15 \mathrm{~min}$ and then the gradient returned at the initial conditions.

The wine samples were filtered by a $0.45 \mathrm{im}$ pore size membrane filter before injection. The amount of phenolic compounds in the extracts was calculated as $\mathrm{mg} / \mathrm{L}$ wine using external calibration curves, which were obtained for each phenolic standard.

In order to test the effect of SBA-15 in phenolic compounds retention, $100 \mathrm{~mL}$ of Romanian red wine were mixed with $1.02 \mathrm{~g}$ of SBA-15 for $50 \mathrm{~min}$ and kept for $48 \mathrm{~h}$ at $4^{\circ} \mathrm{C}$. The solid adsorbent was filtered, dried at the room temperature and then the filtered wine was used for the analysis of remained phenolic compounds. Two samples of Romanian red wines were used, codified as follows: J 187 and M197.

\section{Results and discussions}

The physisorption isotherm of SBA-15 is shown in figure 1 , with the corresponding data in table $1 . N_{2}$ isotherm exhibits the characteristic type IV isotherms with step increases in adsorption at $\mathrm{P} / \mathrm{P} 0 \gg 0.7-0.8$ [22]. The hysteresis loop has sharp adsorption and desorption branches indicating a narrow mesopore size distribution and a good quality of the obtained sample.

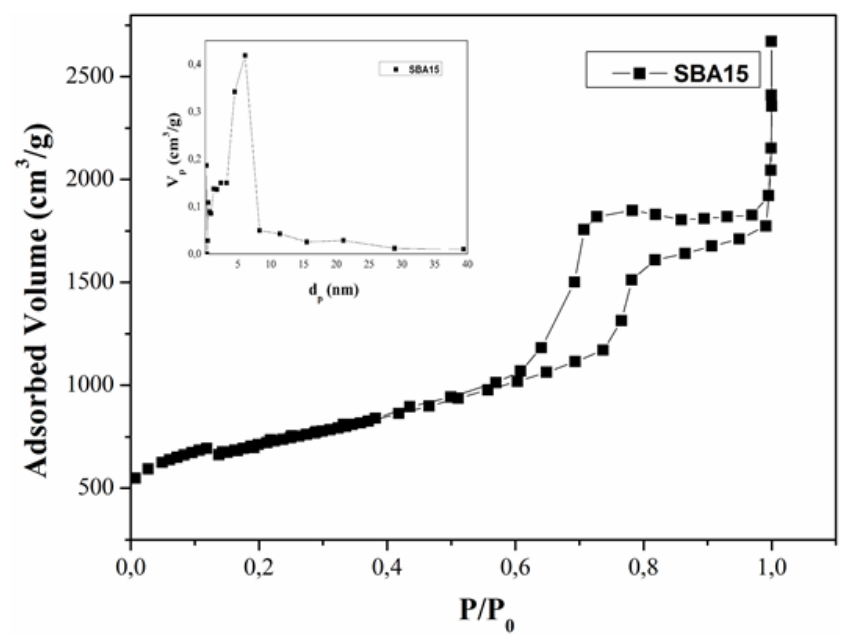

Fig. 1. Adsorption/desorption isotherm and pores distribution of calcinated SBA-15

Table 1

TEXTURAL PROPERTIES RESULTED FROM N $\mathrm{N}_{2}$ ADSORPTIONDESORPTION ISOTHERM

\begin{tabular}{|c|c|c|c|}
\hline Material & SBET $\left(\mathrm{m}^{2} / \mathrm{g}\right)$ & $\mathrm{V}_{\mathrm{mp}}^{\mathrm{a}}\left(\mathrm{cm}^{3} / \mathrm{g}\right)$ & $\mathrm{d}_{\mathrm{p}}^{\mathrm{b}}(\mathrm{nm})$ \\
\hline SBA-15 & 1108 & 0.99 & 6.1 \\
\hline
\end{tabular}

Figure 2 presents the IR spectrum for SBA-15. In the region $3435 \mathrm{~cm}^{-1}, \mathrm{SBA}-15$ presents specific band characteristic with $\mathrm{OH}$ groups from the silanol surface or to the physical adsorbed water from the surface. The band from $1087-1084 \mathrm{~cm}^{-1}$ and $804-797 \mathrm{~cm}^{-1}$ were attributed to $\mathrm{Si}-\mathrm{O}-\mathrm{Si}$ and Si-O vibrations [23]. The absorption band from $1631 \mathrm{~cm}^{-1}$ can be attributed to stretching vibrations of adsorbed water molecules $\left(\mathrm{d}_{\mathrm{H}-\mathrm{-}-\mathrm{H}}\right)$. The band from $960 \mathrm{~cm}$ ${ }^{1}$ was attributed to Si-OH stretching [24].

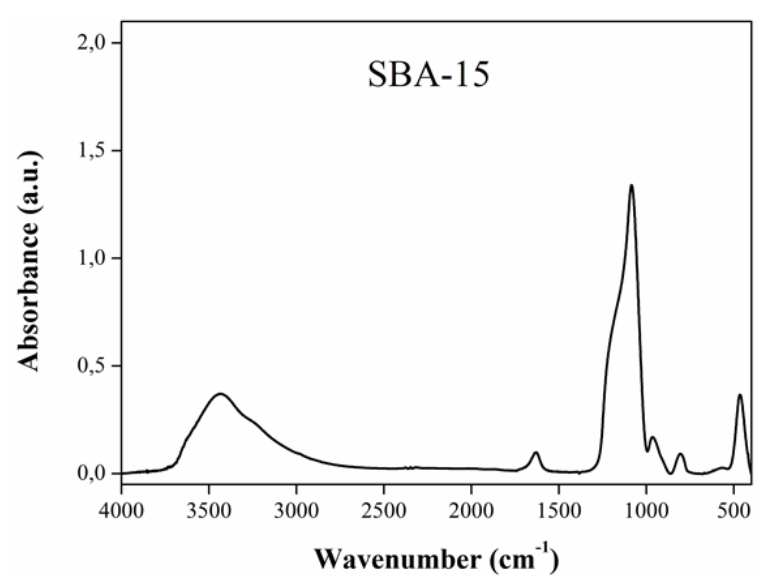

Fig. 2. FT-IR spectrum of calcinated SBA-15 sample 


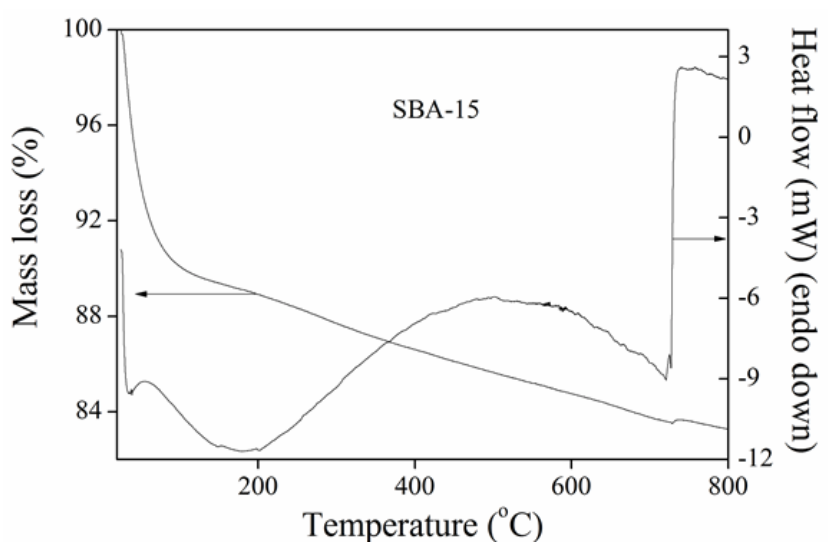

Fig. 3. Thermogravimetric analysis of SBA-15

DSC represents thermal analysis method for detection of materials physical and chemical properties modifications as a function of temperature by measuring the heating modifications associated with these processes. Figure 3 presents the thermogravimetric and DSC analysis of SBA-15 and the associated mass losses.

TG analysis of SBA-15 demonstrates that there are two major regions of mass losses. The first region is in the 0 $100^{\circ} \mathrm{C}$ interval, attributed to water molecules losses [25]. The mass loss continues after this temperature and it is attributed to residual triblock polymer degradation, conversion of residual carbon from triblock polymer to carbon dioxide and carbon monoxide, siloxane bridges growth (Si-O-Si) and also, after $600^{\circ} \mathrm{C}$, to SBA- 15 sintering [26]. Calculating the total mass loss, it can be observed that: for SBA-15, the mass loss is $17 \%$, which is in accordance with the literature data [27].

The obtained mesoporous material was characterized by SEM in order to highlight the morphology and porous structure typical to SBA-15 materials. SEM images for SBA15 put in evidence the typical morphology of this material. There are highlighted the silica chains (fig. 4) and their uniformity.
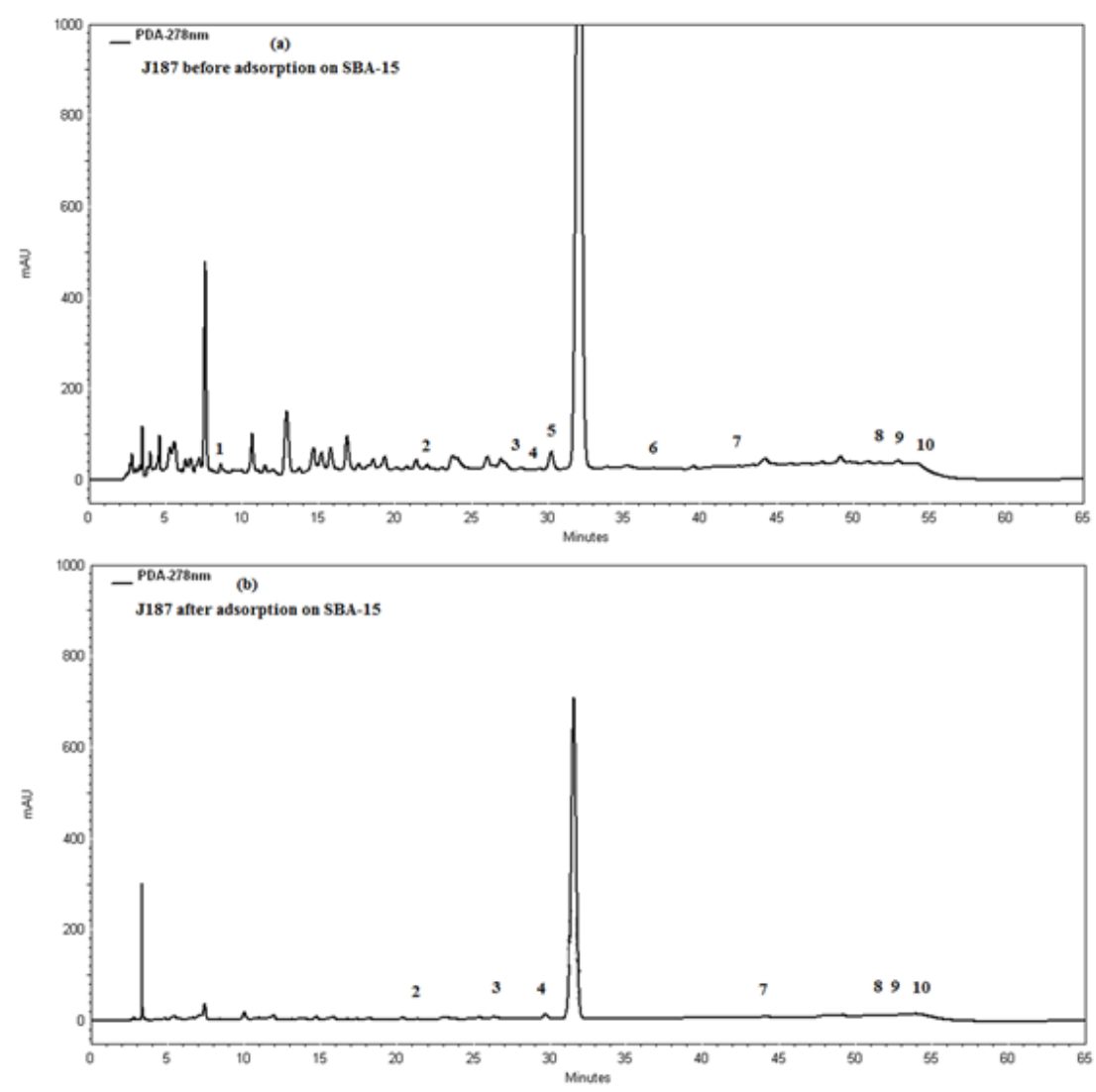

REV.CHIM.(Bucharest) $\bullet 70 \diamond$ No. $5 \bullet 2019$

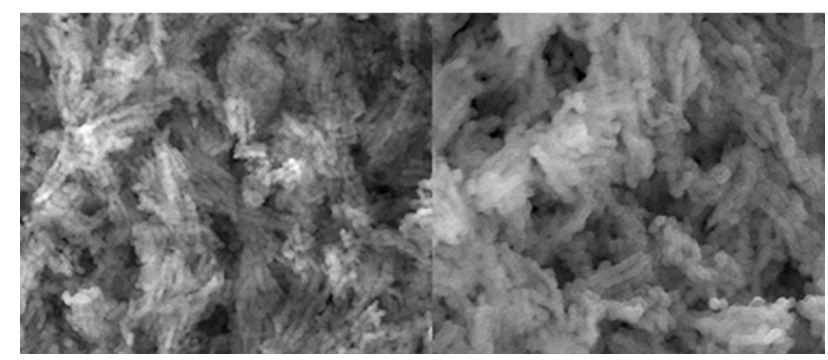

Fig. 4. SEM images for SBA-15

Table 2

STANDARD WINE ANALYSIS

\begin{tabular}{|c|c|c|c|c|}
\hline Wine & $\mathrm{pH}$ & $\begin{array}{c}\text { Ethanol } \\
\% \text { vi }\end{array}$ & $\begin{array}{c}\text { Total dry } \\
\text { matter }(\mathrm{g} / \mathrm{L})\end{array}$ & $\begin{array}{c}\text { Density } \\
(\mathrm{g} / \mathrm{L})\end{array}$ \\
\hline J187 & 3.27 & 10.384 & 95.9 & 1.023 \\
\hline M197 & 3.45 & 12.089 & 31.3 & 0.996 \\
\hline
\end{tabular}

Standard chemical analyses of wine ( $p H$, ethanol, total dry matter and density) were achieved according to the methods proposed by 0.I.V. [28] (table 2).

The total polyphenols, expressed in $\mathrm{mg}$ GAE/L for the two wines were $177.51 \times 10=1775.10 \mathrm{mg} / \mathrm{L}$ for J 187 and $252.12 \times 10=2521.20 \mathrm{mg} / \mathrm{L}$ for M197.

Identification of the phenolic compounds adsorbed on SBA-15 was carried out using HPLC-PDA method. The chromatograms of the native and treated wines are shown in figure 5 and figure 6 , respectively. The peak identification and quantification of the compounds is based on their retention time and external calibration curves obtained for each phenolic compound. Some polyphenolic compounds were only qualitative determined by the retention time, also, being impossible to separate these compounds and evaluate the exact amount for each compound, probably because of the stationary phase in the column. This is the case of syringic acid + vanillin and caffeic acid + chlorogenic acid.
Fig. 5. Chromatogram of J 187 red wine before and after adsorption on SBA-15 


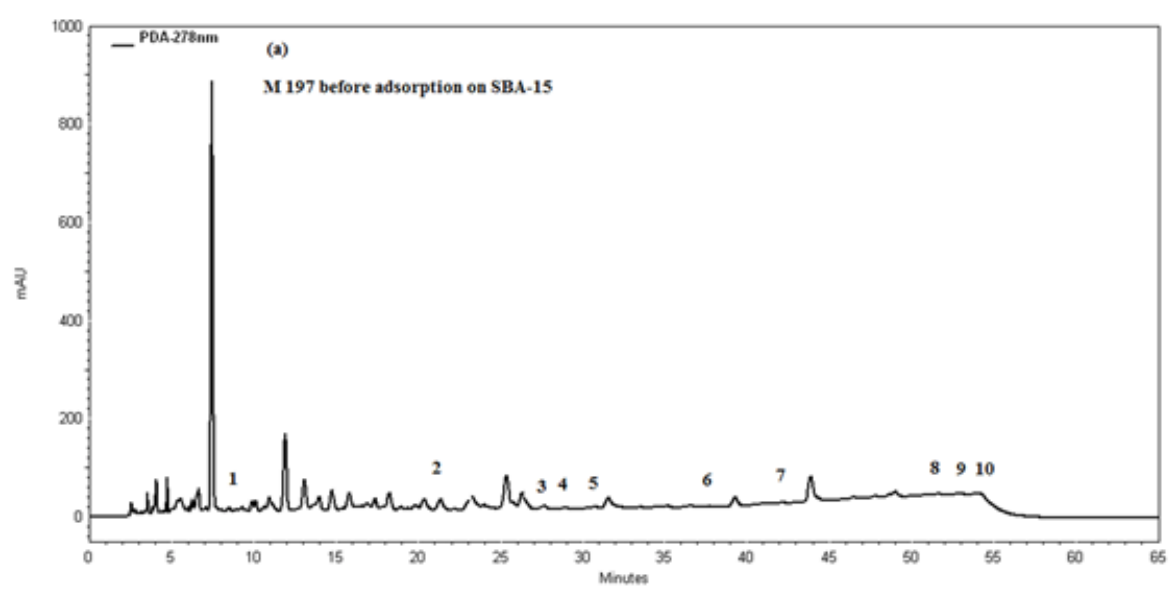

Fig. 6. Chromatogram of M197 red wine before and after adsorption on SBA-15

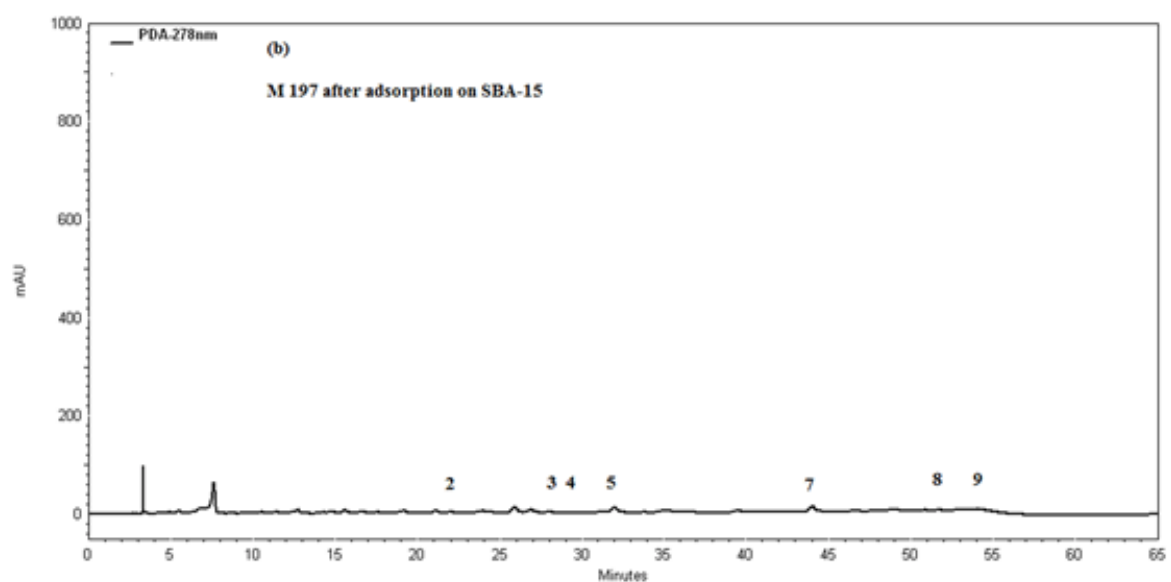

Table 3

POLYPHENOLIC COMPOUNDS IN RED WINES BEFORE AND AFTER ADSORPTION ON SBA-15

\begin{tabular}{|c|c|c|c|c|c|}
\hline \multirow{2}{*}{$\begin{array}{c}\text { Peak } \\
\text { number }\end{array}$} & \multirow{2}{*}{$\begin{array}{c}\text { Name of phenolic } \\
\text { compound }\end{array}$} & \multicolumn{4}{|c|}{ Concentration $(\mathrm{mg} / \mathrm{L})$} \\
\hline & & $\begin{array}{c}\text { J187 } \\
\text { before adsorption } \\
\text { on SBA-15 }\end{array}$ & $\begin{array}{c}\mathrm{J} 187 \\
\text { after adsorption } \\
\text { on SBA-15 }\end{array}$ & $\begin{array}{c}\text { M197 } \\
\text { before adsorption } \\
\text { on SBA-15 }\end{array}$ & $\begin{array}{c}\text { M197 } \\
\text { after } \\
\text { adsorption on } \\
\text { SBA-15 }\end{array}$ \\
\hline 1 & Gallic acid & 0.122 & $\mathrm{BDL}^{\mathrm{a}}$ & 1.880 & $\mathrm{BDL}^{\mathrm{a}}$ \\
\hline 2 & (+)Catechin & 9.408 & 6.125 & 6.884 & 5.330 \\
\hline 3 & $\begin{array}{c}\text { Caffeic acid + chlorogenic } \\
\text { acid }\end{array}$ & $\mathrm{QD}^{\mathrm{b}}$ & $Q^{\mathrm{b}}$ & $\mathrm{QD}^{\mathrm{b}}$ & $\mathrm{QD}^{\mathrm{b}}$ \\
\hline 4 & Epicatechin & 1.870 & 1.720 & 3.846 & 1.296 \\
\hline 5 & Syringic acid $+V$ anillin & $Q^{6}$ & $\mathrm{QD}^{\mathrm{b}}$ & $\mathrm{QD}^{\circ}$ & $\mathrm{QD}^{\mathrm{b}}$ \\
\hline 6 & p-Coumaric acid & 1.763 & $\mathrm{BDL}^{\mathrm{a}}$ & 1.900 & $\mathrm{BDL}^{\mathrm{a}}$ \\
\hline 7 & Ferulic acid & 0.122 & 0.120 & 1.507 & 0.308 \\
\hline 8 & trans-Resveratrol & 0.557 & 0.217 & 0.786 & 0.445 \\
\hline 9 & Rutin & 6.675 & 3.046 & 3.316 & 2.656 \\
\hline 10 & trans-Cinnamic acid & 0.868 & 0.457 & 1.250 & $\mathrm{BDL}^{\mathrm{a}}$ \\
\hline
\end{tabular}

${ }^{3} \mathrm{BDL}=$ below detection limit; ${ }^{6} \mathrm{QD}=\mathrm{Qualitative} \mathrm{Determination}$

By analyzing the chromatograms (fig. 5 and fig. 6), it can be observed that SBA-15 selectively retains phenolic compounds from wine, following the order: catechin> rutin $>$ trans-cinnamic acid > trans-resveratrol $>$ gallic acid. As we mentioned before, the mesoporous SBA-15 has large number of silanol groups, therefore, the adsorption can be attributed to the dipole moment of these molecules. Moreover, the presence of the electrons in phenyl rings and their availability may increase the interaction with $\mathrm{Si}-\mathrm{OH}$ groups and the adsorption.

For the native wines, the concentrations of gallic acid, trans-cinnamic acid and trans-resveratrol are very low (fig.5.a and fig.6.a), decreasing more even after SBA-15 adsorption, even below detection limits, leading to the conclusion that the mesoporous material is capable to concentrate these phenolic compounds from wines. This 
method can constitute the first step for development of new alternatives for trans-resveratrol and other important compounds extraction from wine.

The concentrations of the phenolic compounds found in the two red wines before and after adsorption are included in table 3 , their values being comparable with the literature values $[29,30]$.

\section{Conclusions}

This work has demonstrated the successful application of mesoporous material SBA- 15 for the effective removal and concentration of some important phenolic compounds from red wine as a rapid and easy method. The SBA-15 was prepared using the hydrothermal method and characterized by BET, SEM, IR, TG-DSC, confirming the mesoporous ordered structure.

The adsorption properties of SBA-15 were investigated in retention of phenolic compound from wine at $4{ }^{\circ} \mathrm{C}$ for 48 $h$, by using $1.02 \mathrm{~g}$ SBA-15 for $100 \mathrm{~mL}$ red wine. The total phenols content, expressed as $\mathrm{mg} G A E / L$ was in accordance with literature values for red wines $[29,30]$.

The chromatographic analysis demonstrated that by using SBA-15 as adsorbent, great amounts of important biological principles can be concentrated from wines, which can be used furthermore as dietary sources or pharmaconutrients.

Acknowledgements: This study has been financed by the Romanian Ministry of Education and Research, National Authority for Scientific Research, 19N/2009 NUCLEU Program, under Project PN 09190204: Researches regarding the development of new extraction and separation methods for some vegetal anthocyanic and anthocyanidic compounds in order to use them as food natural colors-Project Responsible PhD Violeta Niculescu

\section{References}

1.KAMBLE, S.P., MANGRLKAR, P.A., BANSIWAL, A.K., RAYALU, S.S., Chem. Eng. J., 138, 1, 2008, p. 73.

2.*** E.U.C. EUROPEAN PARLIAMENT, Off. J. Eur. Communities, L331, 2001, p. 1.

3.TANCREDI, N., MEDERO, N., MOLLER, F., PIRIZ, J., PLADA, C., CORDERO, T., J. Colloid Interface Sci., 279, 2004, p. 357.

4.MOHANTY, K., DAS, D., BISWAS, M.N., Adsorption, 12, no. 2, 2006, p. 119.

5.NAMANE, A., MEKARZIA, A., BENRACHEDI, K., BELHANECHEBENSEMRA, N., HELLAL, A., J. Hazard. Mater., 119, no. 1-3, 2005, p. 189.

6.TANTHAPANICHAKOON, W., ARIYADEJ WANICH, P., JAPTHONG, P., NAKAGAWA, K., MUKAI, S.R., TAMON, H., Water Res., 39, no. 7, 2005, p. 1347.

7.SING, T., K. EVERETT, S.W., HAUL, D.H., MOSCOU, R.A.W., PIEROTTI, L., ROUQUEROL, R.A., SIEMIENIEWSKA, J., Pure Appl. Chem., 57, no. 4,1985 , p. 603.
8.ZHAO, X., LU, G., XU, X., Microporous Mesoporous Mater. 41, no. 1,2000, p. 37.

9.KRESGE, C.T., LEONOWICZ. M.E., ROTH. W.J ., VARTULI. J .C., BECK. J.S., Nature, 359, no. 6397, 1992, p. 710.

10.ANBIA, M., LASHGARI, M., Chem. Eng. J. 150, no. 2-3, 2009, p. 555. 11.BAGSHAW, S.A., PROUZET, E., PINNAVAIA, T.J ., Science, 269, no. 5228, 1995, p. 1242.

12.ZHAO D., FENG, J., HUO, Q., MELOSH, N., FREDRICKSON, G.H., CHMELKA, B.F., STUCKY, G.D., Science, 279, no. 5350, 1998, p. 548. 13.YOKOI, T., YOSHITAKE, H., YAMADA, T., KUBOTA, Y., TATSUMI, T., J. Mater. Chem., 16, no.12, 2006, p. 1125.

14.SILVESTRE-ALBERTO, A., JARDIM, E.O., BRUIJ N, E., MEYNEN, V., COOL, P., SEPULVEDA-ESCRIBANO, A., SILVESTRE-ALBERTO, J., RODRIGUEZ-REINOSO, F., Langmuir, 25, no. 2, 2009, p. 939.

15.DI MAJO, D., LA GUARDIA, M., GIAMMANCO, S., LA NEVE, L., GIAMMANCO M., Food Chem., 111, no. 1, 2008, p. 45.

16.RASTIJA, V., SREÈNIK, G., Food Chem., 115, no. 1, 2009, p. 54.

17.ABE, L.T., VIEIRA, R., MOTA, D.A., LAJOLO, F.M., GENOVESE, M.I., Food Sci. Technol. Campinas, 27, no. 2, 2007, p. 394.

18.ALEN-RUIZ, F., GARCIA-FALCON, M.S., PEREZ-LAMELA, M.C., MARTINEZ-CARBALLO, E., SIMAL-GANDARA, J., Food Chem., 113, no. 1,2009, p. 53.

19.ARTS, M.J.T., HAENEN, G.R.M., VOSS, H.-P., BAST, A., Food Chem. Toxicol., 42, no. 1, 2004, p. 45.

20.PARK, Y., KANG, T., LEE, J., KIM, P., KIM, H., YI, J., Catal. Today, 97, no. 2, 2004, p. 195.

21.GEANA. E.I., IONETE, R.E., TUDORACHE, A., PASA, R., POSTOLACHE, E., Asian J. Chem., 23, no. 12, 2011, p. 5197.

22.THIELEMANN, J .P., GIRGSDIES, F., SCHLOGL, R., HESS, C., BEILSTEIN, J. Nanotechnol., 2, 2011, p. 110.

23.HOANG, V.D., DANG, T.P., DINH, Q.K., NGUYEN, H.P., VU, A.T., AdV. Nat. Sci. Nanosci. Nanotechnol., 1, no. 3, 2010, p. 035011.

24.LIANG, X., XU, Y., SUN, G., WANG, L., SUN, Y., QIN, X., Colloids Surfaces A Physicochem. Eng. Asp., 349, no. 1, 2009, p. 61.

25.POL, V.G., GEDANKEN, A., CALDERON-MORENO, J., Chem. Mater., 15, no. 5, 2003, p. 1111.

26.SAWANT, D.P., VINU, A., JACOB, N.E., LEFEBVRE, F., HALLIGUDI, S.B., J. Catal., 235, no. 2, 2005, p. 341.

27.ZHANG, Y., GAO, F., WAN, H., WU, C., KONG, Y., WU, X., ZHAO, B., DONG, L., CHEN, Y., Microporous Mesoporous Mater., 113, no. 1-3, 2008, p. 393.

28. *** INTERNATIONAL ORGANISATION OF VINE AND WINE, Compendium of International Methods of Analysis of W ines and Musts, 2012.

29.GAMBELLI, L., SANTARONI, G., J. Food Compos. Anal., 17, no. 5, 2004, p. 613.

30. DE LIMA, D.B., AGUSTINI, B.C., DA SILVA, E.G., GAENSLY, F., CORDEIRO, R.B., FAVERO, M.L.D., BRAND, D., MARASCHIN, M., BONFIM, T.M.B., Ciência E Tecnol. Aliment., 31, no. 3, 2011, p. 783.

Manuscript received: 14.06 .2018 